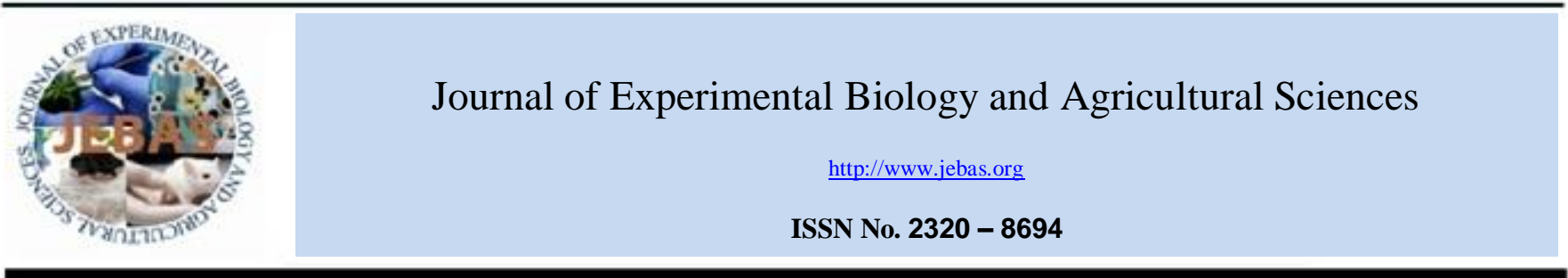

\title{
INHIBITION OF SOME HUMAN BACTERIAL PATHOGENS USING Streptomyces sp. SD5 OBTAINED FROM SOIL SAMPLE FROM JEDDAH
}

\author{
Samyah Jastaniah ${ }^{1}$, Sawsan Dawalibi ${ }^{1}$, Reda Amasha ${ }^{1}$, Magda Aly ${ }^{1,2}$ \\ ${ }^{1}$ Biological sciences Department, Faculty of Sciences, King Abdulaziz University, Jeddah, Saudi Arabia \\ ${ }^{2}$ Department of Botany, Faculty of Science, Kafrelsheikh University, Egypt
}

Received - February 16, 2019; Revision - March 30, 2019; Accepted - April 04, 2019

Available Online - April 10, 2019

DOI: http://dx.doi.org/10.18006/2019.7(2).222.232

KEYWORDS
Antibiotics
Actinomycetes
MRSA
Extraction

\begin{abstract}
For decades, antibiotics are wonder drugs which treat different microbes and human pathogens such as pneumonia, tuberculosis and gonorrhea which are harder and difficult to treat. Due to miss use of antibiotics in agriculture and animal husbandry, antibiotics are becoming less effective and microbes became more resistant. This resistant increased every second, thus this study aimed to produce active antibiotic from soil actinomycetes which might play a highly significant role in medicine. About 15 bacterial isolates were obtained on starch nitrate agar medium from different soil samples. They were screened for antibacterial production against 5 different human pathogens, Escherichia coli, Klebsiella pneumoniae, Pseudomonas aeruginosa, Enterococcus faecalis and Methicillin-resistant Staphylococcus aureus (MRSA). The most active isolate was SD5 which showed the highest inhibition against $E$. coli, E. faecalis and MRSA was morphologically examined and characterized. Using molecular identification technique, it was reported that isolate SD5 belonging to genus Streptomyces and was similar to Streptomyces geysiriensis with 97\% similarity and to Streptomyces sp. JSM147777 with 95\% similarity. Maximum production of the antimicrobial agent was determined by measuring the diameter of inhibition zone using starch nitrate broth, prepared at $\mathrm{pH} 6.5$ and incubation temperature at $30^{\circ} \mathrm{C}$ for 5 days. The antimicrobial agent was extracted by using three different organic solvents (ethyl acetate, $\mathrm{n}$ Butanol and Petroleum ether). The best solvent was ethyl acetate which gave maximum inhibition against $E$. faecalis, E. coli and Methicillin-resistant $S$. aureus. In conclusion, actinomycetes especially
\end{abstract}

* Corresponding author

E-mail: sdjastaniah@kau.edu.sa (Samyah Jastaniah)

Peer review under responsibility of Journal of Experimental Biology and Agricultural Sciences.

Production and Hosting by Horizon Publisher India [HPI] (http://www.horizonpublisherindia.in/).

All rights reserved.
All the article published by Journal of Experimental Biology and Agricultural Sciences is licensed under a Creative Commons Attribution-NonCommercial 4.0 International License Based on a work at www.jebas.org.

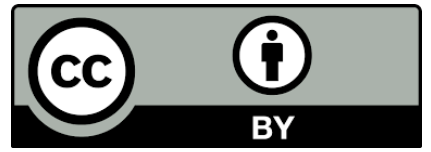


genus Streptomyces obtained from soil still contained new isolates with excellent antimicrobial activities. Ethyl acetate is a good solvent for antimicrobial agent extraction (MIC ranged from $75-100 \mu \mathrm{g} / \mathrm{ml}$ ) and no toxicity was recorded for all tested organic extracts at the different concentrations using Artemia salina as test organism. Purification and characterization of the antimicrobial agent must be carried out to obtain new material active against Methicillin-resistant S. aureus.

\section{Introduction}

Bacterial infection and antibiotic resistance are major health problems that cause human death. It is very important to use antibiotics in a rational manner to improve patient outcomes and minimize the appearance of antimicrobial resistance. Several reasons made the inappropriate use of antibiotic is costly because it was inefficacy, increased morbidity and mortality, extra drugs are used unnecessarily for long period of time and increased rates of resistance in bacteria (Luna et al., 2010). Antibiotic consumption is correlated with the level of bacterial resistant. In recent years, Methicillin-resistant S. aureus (MRSA) became resistant to almost all antibiotic, thus cause serious skin and underlying tissue infections (Peacock \& Paterson, 2015). Alternative therapies with new antibiotics from natural sources are needed to solve these problems. One of the most famous antibiotics is Streptomycin, produced from Actinomycetes, played a significant role in drug discovery programs and often leads to discoveries of newer antimicrobial agents from different isolates, versatility and immense economic value (Berdy, 2005). Further, it was reported that the most promising resource for antibiotics is actinomycete groups which undoubtedly considered as important resources of active by products (Agwa et al., 2000). Scientist considered Actinomycetes, especially genera Streptomyces and Micromonospora as the most economically and biotechnologically useful microorganisms (Torsvik \& Ovreas, 2002; Pandey et al., 2004; Frieden, 2013). They are extremely noteworthy and considered a sustain supply of new antibiotics that kill pathogens without disturbing the host cells (Ghanem \& Aly, 2003; Aly \& Sabbagh, 2004; Amer et al., 2006). These antibiotics have different mode of action and poses antibacterial, antifungal antitumor and wound healing properties and each one has unique mode of action (Amer et al., 2006; Rabbah et al., 2006; Rabbah et al., 2007; Jiao et al., 2013; Janardhan et al., 2014). More than two hundreds of antibiotics such as Beta-lactam peptide antibiotics, macrolide, tetracyclines, aminoglycosides, daptomycin and tigecycline were used and half of them are obtained from actinomycetes (Kekuda et al., 2010; Naine et al., 2011; Kaur \& Narayan, 2014; Kaur \& Chate 2015). Actinomycetes act as factory microbes for production of many important antibiotics, different vitamins, enzymes, enzyme inhibitors, and siderophores in addition to many secondary products with pharmaceutical and clinical applications (Koehn \& Carter, 2005; Aly et al., 2013; Tork et al., 2018). The discovery of new antibiotics for bacterial resistance especially to MRSA, which caused serious public health problem, has continued in many countries. This paper aimed to isolate an antibiotic from actinomycetes with emphasis on the isolation source, extraction and antimicrobial activity.

\section{Materials and Methods}

\subsection{Soil sample collection}

Ten different soil samples were collected from hospital, house and University gardens, located at Jeddah, Saudi Arabia. These soil samples were dried and used to isolate some actinomycetes on starch nitrate agar (Shirling \& Gottlieb, 1966) at $30^{\circ} \mathrm{C}$.

\subsection{Tested bacterial pathogens}

Standard bacterial isolates that are known for being involved in the pathogenesis of human were collected from King Faisal Hospital and Research Center, Jeddah, Saudi Arabia. These bacterial isolates were E. feacalis, $S$. aureus (MRSA), $P$. aeruginosa, E. coli and K. pneumonia.

\subsection{Isolation of actinomycetes from soil samples:}

From collected soil samples, different actinomycete isolates were obtained on starch nitrate agar (SNA) medium. One gram of the soil sample was suspended in $9.0 \mathrm{ml}$ of distilled water, the obtained suspension was mixed well and serial dilution was carried out up to the $10^{-3}$. From this suspension, $0.5 \mathrm{ml}$ of suspension was spread on plates of medium. All plates were incubated at $30^{\circ} \mathrm{C}$ for 4 days. All the obtained colonies were purified on the same medium until pure colonies were obtained. All the purified colonies were transferred to slants of starch nitrate agar and refrigerated at $4{ }^{\circ} \mathrm{C}$ to preserve the isolates from 3 to 6 months. For longer preservation (more than six months), the selected pure isolates were kept in Tryptic soy broth with glycerol and stored in deep freezer at $-80^{\circ} \mathrm{C}$ until used.

\subsection{Screening of Actinomycetes isolates for antibacterial activities on solid medium}

Screening of actinomycete isolates for antibacterial activities was done by agar disc diffusion method on Mueller Hinton agar, obtained from Sigma-Aldrich, (Hindler \& Inderlied, 1985). A 7 $\mathrm{mm}$ diameter disk of the tested actinomycete isolate was bored by cork- borer from the SNA medium that were incubated at $30^{\circ} \mathrm{C}$ for 4 days. This disc was placed on MHA plate which was previously 
inoculated with the tested bacterium. Then, all plates were incubated at $37^{\circ} \mathrm{C}$ for $24 \mathrm{hrs}$. After incubation of the Mueller Hinton agar plates, the obtained inhibition zone was measured three times in $\mathrm{mm}$ and mean value was recorded for each bacterium. The isolates of actinomycetes that gave the largest inhibition zone were selected and grown in starch nitrate broth medium for 4 days and culture filtrates were tested for any antimicrobial activates against the tested bacterial pathogens Westley et al. (1979).

\subsection{Preparation of the preculture}

Preculture was used to inoculate the main medium with a constant number of the tested bacterium. Starch nitrate broth medium was used as preculture medium for the growth of bacterial isolates. In $250 \mathrm{ml}$ Erlenmeyer flasks containing $50 \mathrm{ml}$ of the fresh sterile starch nitrate broth, $2 \mathrm{ml}$ of the selected bacterium suspension were added. The flasks were incubated at $30^{\circ} \mathrm{C}$ on shaker incubator for 4 days. Each 2 $\mathrm{ml}$ of the preculture was used to inoculate each flask containing $48 \mathrm{ml}$ of the prepared medium.

\subsection{Bacterial growth in liquid medium}

All bacterial isolates were named and numbered, SD1 to SD15, then all isolates were screened for antibacterial agent production and isolate SD5 was the most active. Each flask of starch nitrate broth was inoculated with the selected isolate SD and the flasks were incubated at $30 \mathrm{C}$ for a period of 4 days on shaking incubator $(120 \mathrm{rpm})$. Cells were collected after centrifugation at $5000 \mathrm{rpm}$ for $15 \mathrm{~min}$. the culture filtrate was sterilized using 0.22 bacterial filter and its antibacterial Activity was determined using agar well diffusion assay.

\subsection{Determination of the Antibacterial Activity of chosen isolate SD5}

Cells of all tested bacterial pathogens were suspended in sterile normal saline, adjusted at 0.5 McFarland turbidity standards and 100 $\mu \mathrm{l}$ of this suspension was used to inoculate on $\mathrm{MH}$ agar plates using sterilized cotton swabs. More than one well was done in each plate using sterile cork borer and $100 \mu 1$ from the culture filtrate of the isolate SD5 were added to each well $(7 \mathrm{~mm}$ diameter holes cut by cork borer in the $\mathrm{MH}$ agar). All plates were incubated at $37^{\circ} \mathrm{C}$ for $24 \mathrm{~h}$. After incubation, bacterial growth was observed and inhibition zone diameter was measured and recorded in $\mathrm{mm}$.

\subsection{Determination of minimum inhibitory concentration (MIC) by Broth microdilution method}

The minimum inhibitory concentrations (MICs) were determined using Broth microdlution method as described by Bonnavero et al. (1998) with some modifications. This test was carried out to determine MIC of the tested cultured extract against the selected bacteria pathogens. Nutrient broth was used to grow the bacteria overnight and the growth was diluted to approximately $10^{4} \mathrm{cfu} / \mathrm{ml}$ and 7 drops of phenol red as a colorimetric indicator was added to clarify the end point by color change from yellow to pink. Nutrient broth with some drops of phenol red indicator was added into 12 wells in a micro titer plate $(125 \mu \mathrm{l} / \mathrm{well})$, then $125 \mu \mathrm{l}$ of the selected culture extract along with DMSO was added to well no. 1 and the mixture was mixed. For serial dilution, about $125 \mu 1$ of the well no. 1 was transferred to well 2 and so on and keep diluting the mixture, in this manner through well no. 11. No culture extracted mixture was transferred to well no. 12 (control). Three replicates were prepared and the microtiter plate was incubated at $37^{\circ} \mathrm{C}$ overnight. MIC was determined by the concentration $(\mu \mathrm{g} / \mathrm{ml})$ changing in color of the broth from yellow to pink (NCCLS, 2002).

\subsection{Measuring of bacterial growth in liquid medium}

Detection of bacterial growth in culture filtrates by measuring the optical density at $520 \mathrm{~nm}$ using UV spectrophotometer by adding $3 \mathrm{ml}$ from the fresh filtrate in sterile cuvette. All observations were carried out in triplicate and averages were calculated.

\subsection{Optimization factors of culture conditions and producing of antimicrobial activities}

Growth estimation (determined by the optical density at $625 \mathrm{~nm}$ using UV spectrophotometer) and antibacterial activities (measured by agar well diffusion method on MH agar plates) were determined in the end of study. Effect of different broth media, $\mathrm{pH}$ value, temperate and incubation time on growth and antibacterial production was determined (Agwa et al., 2000). The tested medium was prepared in $250 \mathrm{ml}$ flasks with $50 \mathrm{ml}$ of the selected medium and inoculated with $2 \mathrm{ml}$ of the prepared preculture of SNB and incubated in shaking incubator (120 rpm). Three replicates were maintained for each factor. Effect of different culture media such as starch nitrate broth (Shirling \& Gottlieb, 1966), GBA-3 broth medium (Agwa et al., 2000), Emerson medium (Agwa et al., 2000), Omura medium (Omura et al., 1982), yeast extract starch peptone medium (ATCC 435) and Nutrient broth on microbial growth or antibiotic production was detected. The effect of different initial $\mathrm{pH}$ values, $(\mathrm{pH} 5,5.5,6$. 6.5, 7 and 7.5) different incubation temperatures $\left(20-45^{\circ} \mathrm{C}\right)$ and different incubation periods (2-7 days) on biomass and production of antimicrobial activity was determined.

\subsection{Extraction of the antibacterial compound produced by} the selected isolate

Extraction of the antimicrobial compound from the supernatant with equal volumes of different solvents (Ethyl acetate, Petroleum ether or n-Butanol) was carried. The solvent was evaporated, the resulting material was dissolving in one $\mathrm{ml}$ of DMSO and the antimicrobial activity against of gram-positive and gram-negative bacteria was determined using agar well diffusion assay. The antibacterial activities of DMSO (negative control) and Ampicillin (positive control) were also determined. 


\subsection{Identification of the selected bacterial isolate SD5}

2.12.1 Morphological and physiological characterizations of the bacterial isolate SD5

The best antibacterial activities was selected and identified. The selected bacterial isolate SD5 was cultivated on Starch nitrate agar and identified according to morphology, physiology and biochemical characters. The cellular morphology of the bacterial isolate SD5 was examined under light microscope and scanning electron microscope. Cell shape, colony color and spore shape were recorded (Aly et al., 2013).

\subsubsection{Isolation of genomic DNA and PCR amplification of 16S rRNA}

The DNA of the isolate SD5 was extracted by the method given by Otsuki et al. (1996). For this, a loop full of cells from SD5 bacterial colony grown on an overnight $\mathrm{LB}$ agar plate (Hi media) at $37^{\circ} \mathrm{C}$ was transferred to $1.5 \mathrm{ml}$ eppendorf tube with $200 \mu \mathrm{l}$ sterile distilled water. It was boiled for $20 \mathrm{~min}$, frozen and thawed twice centrifugation was performed at 12,000 rpm for $5 \mathrm{~min}$. Crude DNA extract of cells (fresh preparation) from this strain was obtained and subjected to PCR amplification using DNA thermal cycler (Perkin Elmer, USA). The primers were designed based on the highly conserved region of 16S rRNA from various bacteria (Weisburg et al., 1991). The following primers 5'- AGTTTGATCATGGTCAG-3' and 5'-GGTTACCTTGTTACGACT 3' were used to amplify $16 \mathrm{~S}$ rRNA gene. The purified PCR product of $1,517 \mathrm{bp}$ was sequenced and analyzed by using DNA sequencer ABI PRISM 310 genetic analyzer (Perkin Elmer, USA). The DNA sequence was compared to the Gen Bank database in the National Center for Biotechnology Information (NCBI) using the BLAST program.

\subsection{Cell toxicity using Artemia salina as test organism}

Toxicity of the culture filtrate was determined against Artemia salina (test larva). The toxicity of the obtained extract in DMSO was conducted using larvae of a microcrustacean species, A. salina as test organism as described by Sangian et al. (2013). Eggs of A. salina were suspended in sterile sea water ( $\mathrm{pH} 8.5$ ). Eggs were allowed to hatch under light at $25^{\circ} \mathrm{C}$ with continuous aeration. After $48 \mathrm{hr}$ of cyst hatching, ten living larvae were collected and put in different concentrations of the tested material and every treatment was prepared three times. DMSO was used as negative control while $0.1 \%$ solution of $\mathrm{CuSO}_{4}$ was used as positive control. The percentages of surviving or dead larvae were determined after $8 \mathrm{hr}$ and lethal dose (LD50) was determined according to Meyer et al. (1982) and Aly \& Gumgumjee (2011).

\subsection{Statistical analyses}

The statistical data are expressed as means plus standard deviation and one-way ANOVA was used for statistical to compare the results. Tukey test ( $t$ - test) was considered significant at $\mathrm{p} \leq 5 \%$.

\section{Results and Discussion}

Out of ten soil samples, 15 isolate of actinomycetes were obtained from soil of the hospital garden, house garden and university garden, located in Jeddah, Saudi Arabia (Table 1). These isolates have different colors and produced different pigments. The growth

Table 1 Source, color, growth and pigment production of the actinomycete isolates, obtained on starch nitrate agar medium

\begin{tabular}{|c|c|c|c|c|c|}
\hline Isolate & Source & Colony color & Growth & Pigment & $\begin{array}{l}\text { Antimicrobial activities } \\
\text { (E. coli) }\end{array}$ \\
\hline SD1 & Hospital garden & Gray to white & Heavy & Black & + \\
\hline SD2 & Hospital garden & White to gray & Heavy & No pigment & + \\
\hline SD3 & Hospital garden & Off white & Heavy & Pink & - \\
\hline SD4 & Hospital garden & Off white & Heavy & Dark pink & - \\
\hline SD5 & Hospital garden & Gray & Moderate & Orange & ++ \\
\hline SD6 & Hospital garden & Gray & Heavy & Orange & + \\
\hline SD7 & Hospital garden & Gray & Moderate & yellow & + \\
\hline SD8 & University garden & White & Light & No pigment & ++ \\
\hline SD9 & University arden & Gray & Heavy & White & - \\
\hline SD10 & Hospital garden & Gray to pink & Heavy & Dark pink & + \\
\hline SD11 & Hospital garden & black & Heavy & Bright green & ++ \\
\hline $\mathrm{SD} 12$ & Hospital garden & Dark gray & Heavy & Green & - \\
\hline SD13 & Hospital garden & white & Moderate & Light yellow & - \\
\hline SD14 & House garden & Orange & Heavy & Yellow & + \\
\hline SD15 & House garden & White & Moderate & Dark pink & ++ \\
\hline
\end{tabular}


Table 2 The antimicrobial activities of 4 isolates of Actinomycetes against different bacterial pathogens

\begin{tabular}{|c|c|c|c|c|c|}
\hline \multirow{2}{*}{$\begin{array}{l}\text { Tested } \\
\text { isolate }\end{array}$} & \multicolumn{5}{|c|}{ Mean diameter of inhibition zone measured by $\mathrm{mm}$} \\
\hline & Escherichia coli & $\begin{array}{c}\text { Klebsiella } \\
\text { pneumoniae }\end{array}$ & $\begin{array}{c}\text { Pseudomonas } \\
\text { aeruginosa }\end{array}$ & Enterococcus faecalis & MRSA \\
\hline SD5 & $20 \pm 0.22 *$ & $14 \pm 1.23 *$ & $13 \pm 0.29 *$ & $21 \pm 0.42^{*}$ & $19 \pm 0.29 *$ \\
\hline SD9 & $11 \pm 0.42 *$ & $11 \pm 0.67 *$ & $11 \pm 0.89 *$ & $12 \pm 0.44 *$ & $14 \pm 1.34$ \\
\hline SD11 & $15 \pm 0.27 *$ & $14 \pm 0.99 *$ & $14 \pm 0.77 *$ & $11 \pm 0.67 *$ & $11 \pm 0.79$ \\
\hline SD15 & $14 \pm 1.02 *$ & $11 \pm 0.45^{*}$ & $12 \pm 0.46^{*}$ & $11 \pm 0.88 *$ & $11 \pm 1.95$ \\
\hline Ampicillin (control) & $39 \pm 0.44$ & $34 \pm 1.21$ & $43 \pm 0.20$ & $29 \pm 0.31$ & $11 \pm 0.11$ \\
\hline
\end{tabular}

*: significant results at $\mathrm{p}<0.05$ compared to control, MRSA: Methicillin-resistant Staphylococcus aureus

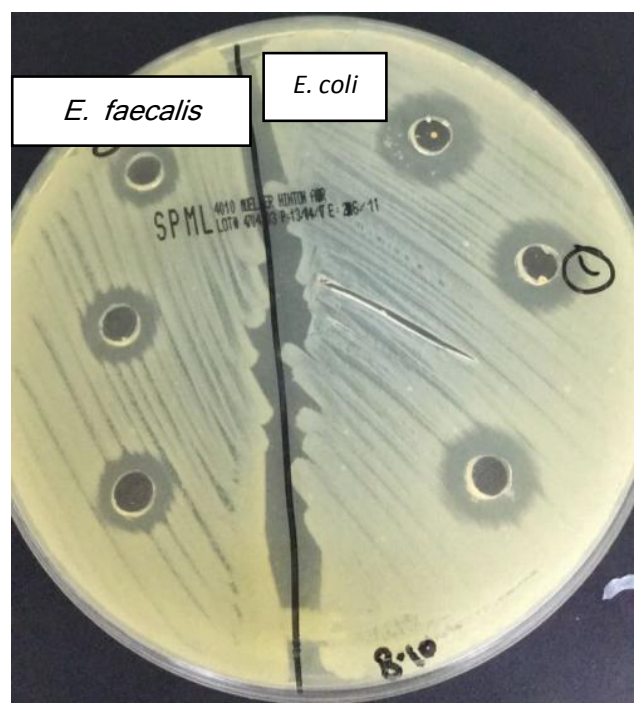

Figure 1 The effect of the selected culture filtrate of the isolate SD5 on two human bacterial isolates, E. coli and E. faecalis

of the isolated microorganisms on starch nitrate agar was heavy, moderate or poor. In many clinical microbiology laboratories, agar disk-diffusion method is the official method used for routine antimicrobial susceptibility testing. The disk diffusion method was used where agar disc of heavy growth was transferred to a solid medium, inoculated with the test pathogen, appearance of an inhibiting growth halo around the disc, meaning positive results. The diameter of the inhibition zone is proportional to the activity of the tested isolate in antibiotic production (Salami, 2004). Ebadi et al. (2018) used the same technique for isolation of active actinomycetes in antibiotics productions. The isolates SD 5, 9, 11 and 15 showed excellent antibacterial activities against the five tested bacteria (Table 2). The isolate SD5 was the most active isolate against E. coli, E. faecalis K. pneumoniae, P. aeruginosa, and MRSA. Figure 1 showed the activities of the isolate SD5 against E. coli and E. faecalis. The selected actinomycete was identified using morphological and physiological characteristics. Isolated microorganism was Gram positive filamentous bacterium, bearing aerial and substrate mycelia, grew well on starch nitrate medium (Figure 2). It belongs to the grey series
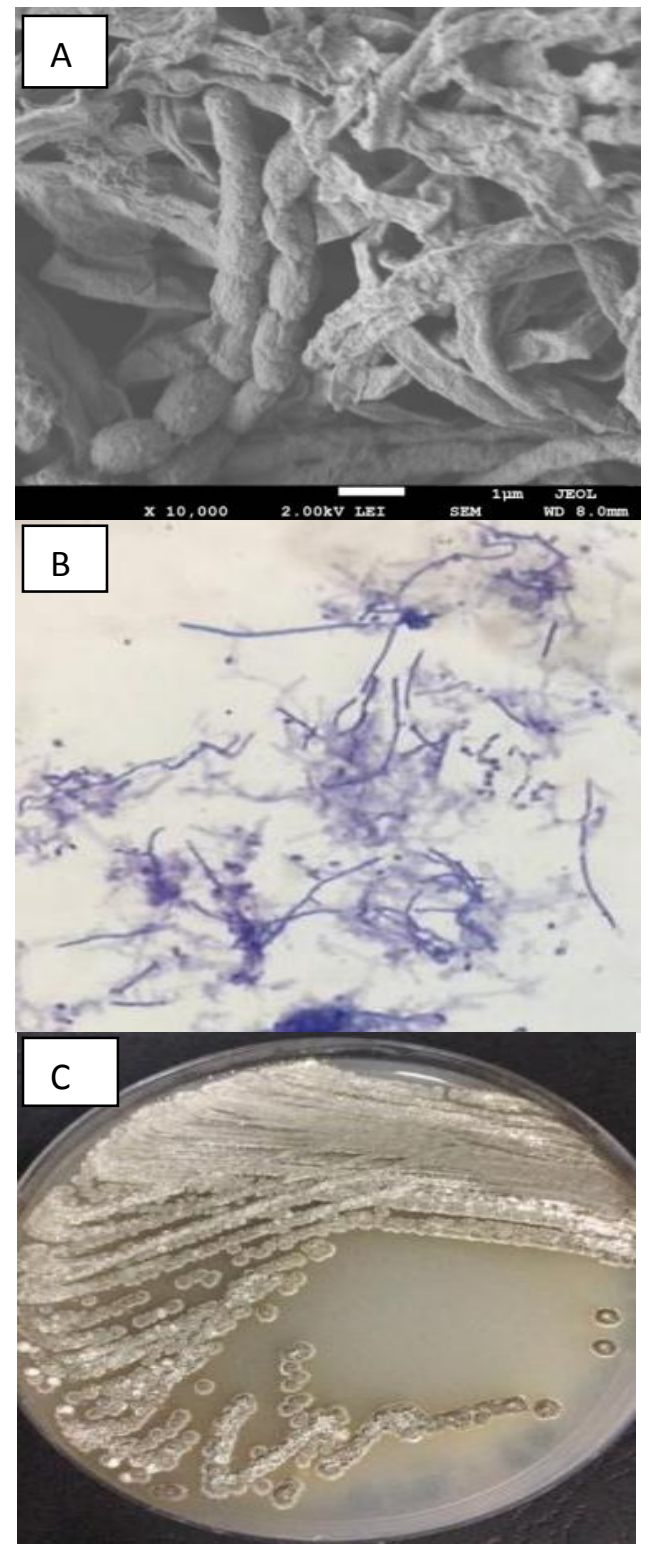

Figure 2 The selected actinomycete SD5 under scanning electron microscope (A), Light microscope (B) and on starch nitrate agar (C) 


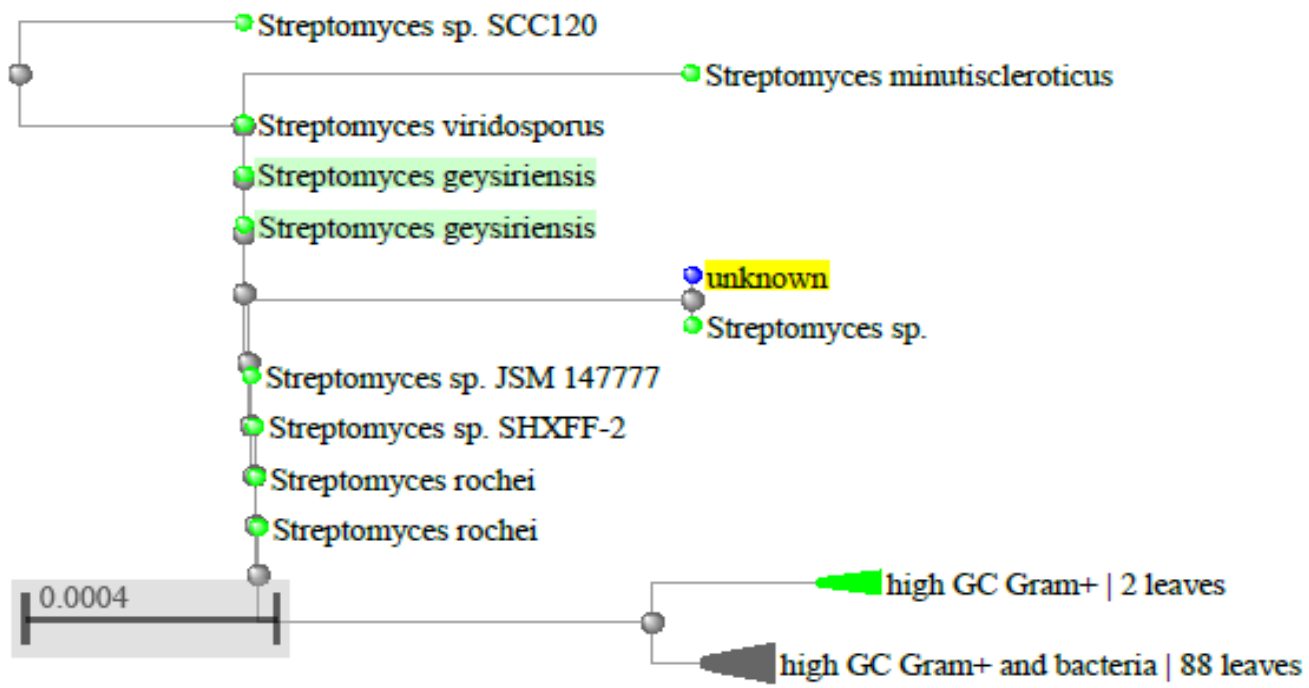

Figure 3 Phylogenetic tree of the selected isolate SD5 with the most related genera

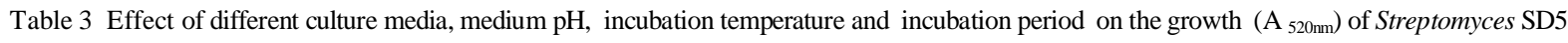

\begin{tabular}{|cccccccc|}
\hline Media & $\begin{array}{c}\text { Biomass } \\
(\mathrm{A} 520 \mathrm{~nm})\end{array}$ & $\mathrm{pH}$ & $\begin{array}{c}\text { Biomass } \\
(\mathrm{A} 520 \mathrm{~nm})\end{array}$ & $\begin{array}{c}\text { Temp. } \\
\left({ }^{\circ} \mathrm{C}\right)\end{array}$ & $\begin{array}{c}\text { Biomass } \\
(\mathrm{A} 520 \mathrm{~nm})\end{array}$ & Incubation period & $\begin{array}{c}\text { Biomass } \\
(\mathrm{A} 520 \mathrm{~nm})\end{array}$ \\
\hline Yeast extract starch peptone & $1.29 \pm 0.06$ & 5.0 & $1.16 \pm 0.06$ & $20^{\circ} \mathrm{C}$ & $0.768 \pm 0.06$ & 2 days & $0.22 \pm 0.36$ \\
\hline GBA-3 & $1.70 \pm 0.12^{*}$ & 5.5 & $0.97 \pm 0.16^{*}$ & $25^{\circ} \mathrm{C}$ & $0.911 \pm 0.30^{*}$ & 3 days & $1.54 \pm 0.41^{*}$ \\
\hline Emerson & $1.67 \pm 0.25^{*}$ & 6.0 & $1.26 \pm 0.26^{*}$ & $30^{\circ} \mathrm{C}(\mathrm{control})$ & $1.90 \pm 0.64$ & 4 days (control) & $1.85 \pm 0.33$ \\
\hline Omura & $0.81 \pm 0.23^{*}$ & 6.5 & $1.80 \pm 0.11$ & $37^{\circ} \mathrm{C}$ & $0.916 \pm 0.09^{*}$ & 5 days & $1.63 \pm 0.21^{*}$ \\
\hline Starch nitrate & $1.85 \pm 0.26^{*}$ & $7.0($ control) & $1.85 \pm 0.42$ & $40^{\circ} \mathrm{C}$ & $0.828 \pm 0.08^{*}$ & 6 days & $1.49 \pm 0.04^{*}$ \\
\hline Nutrient broth (control) & $1.05 \pm 0.56$ & 7.5 & $1.17 \pm 0.11^{*}$ & $45^{\circ} \mathrm{C}$ & $0.928 \pm 0.17^{*}$ & 7 days & $1.38 \pm 0.63^{*}$ \\
\hline
\end{tabular}

actinomycetes. It was identified as species belong to genus Streptomyces. Results of molecular identification revealed that the identified was very similar to Streptomyces sp. SCC120, S. minutiscleroticus, $S$. viridosporus, $S$ geysiriensis, Streptomyces sp. JSM 147777, Streptomyces sp. SHXFF-2 and S. rochei (Figure 3). Aliero et al. (2018) used molecular characterizations for identification of actinomycete isolates with antimicrobial activities. The unique group of gram-positive, spore forming bacteria with abilities of mycelia formation which named actinomycetes is the richest reservoir of secondary metabolites especially medicinal antibiotics (Ebadi et al., 2018). The most important antibiotics, streptomycin, gentamycin, rifamycin and erythromycin are obtained from these bacteria and many pharmaceutical and agricultural industries are depending on these well established antibiotic drugs (Kumar et al., 2010). These actinomycetes were mainly isolated from soil, wastes and waters (Jeffrey, 2008; Aly et al., 2012; Aly et al., 2013; Aly et al., 2015). The best genus of soil actinomycetes for antibiotics production is genus Streptomyces where all species of this genus produced potent secondary metabolites.
Factors affecting growth and antibiotic productions were studied for optimization the growth conditions for maximum antibiotic production. The growth of the selected bacterium was determined in different media, incubation temperature, $\mathrm{pH}$ values and incubation period. At the end of the growth period, the growth was determined by the absorbance at $520 \mathrm{~nm}$ (Table 3). High growth was recorded in starch nitrate broth, GBA-3 broth, Emerson medium and yeast extract starch peptone medium while poor growth was recorded in Omura medium and moderate growth was observed in nutrient broth medium. It was found that the selected bacterium showed maximum growth on starch nitrate medium at $\mathrm{pH} 6.5$ and $\mathrm{pH} 7$ and incubation temperature at $30^{\circ} \mathrm{C}$ for incubation period of 4 days (Table 3 ).

Similarly, the antimicrobial activities of the isolate SD5, determined by the diameter of the inhibition zone $(\mathrm{mm})$ on the agar plate, previously inoculated of the selected bacterial pathogen, was affected by growth conditions. The growth inhibition was recorded against E. coli, E. faecalis (Gram negative) and MRSA (Gram positive). It was well reported that $E$. 
faecalis considered as predominant species but now in many US hospitals $90 \%$ of clinical isolates were reported to cause nosocomial and healthcare associated infections (Laverde Gomez et al., 2011). Infection with E. coli usually associated with bacteraemia and is the common cause of urinary tract infections which may cause tachycardia, fever, tachypnoea and delirium (Lee et al., 2018). Although, E. coli infections in some cases cause uremia, liver failure, acute respiratory infections, coma and death, endotoxin led to intravascular coagulation and death (Madappa, 2014; Woodward, 2015; Zaman et al., 2015). Similarly, MRSA is a potent bacterial infection caused many pneumonia cases which were acquired during hospital and healthcare stay. Initial empiric therapy considered MRSA as possible etiologic agents (American Thoracic Society, 2005; Shittu et al., 2009). MRSA may cause Healthcare-related pneumonias, hospital-acquired pneumonia and ventilator-associated pneumonia. Strains of $S$. aureus have resistance against some commonly used classes of antibiotics including penicillins and cephalosporins, which used to treat both clinic and hospital patients (Moran et al., 2006; Hyun et al., 2009). For the treatment of MRSA, the current arsenal of antibiotics available are limited and used intravenously. In Latin American hospitals between 2003 and 2008, Sader et al. (2009) studied the resistant pattern of antibiotic among Gram-positive bacteria obtained from bloodstream, skin and infected soft tissue. The antibiotic, mupirocin inhibited synthesis of protein and ribonucleic acid (RNA) in cells of bacteria prolonged and intense use of mupirocin (including for decolonization purposes) has resulted in certain MRSA strains developing resistance to this antibiotic (Shittu et al., 2009). According to Helmi et al. (2013), discovering new agents for MRSA resistant isolates is very important.

Five different growth medium were tested but starch nitrate broth medium was the best medium for antimicrobial agent production by the isolate SD5 against the three tested bacterial pathogens, MRSA, E. faecalis and E. coli (Figure 4). Previous study suggested that starch nitrate broth medium enhanced enzyme and antimicrobial production against many pathogens (Agwa et al., 2000; Tork et al., 2018). Aliero et al. (2018) reported that optimization of culture conditions including medium components, initial $\mathrm{pH}$ value, incubation temperature and time are important for the production of antimicrobial agents from actinomycetes obtained from soil of Western Uganda. Using shake flask cultures and eight different media, modified nutrient broth supplemented with soluble starch and glycerol supported bioactive compound production by actinomycetes. Aqueous and ethanol extracts gave optimum bioactive activity for all the three organisms. The identification of 16SrDNA gene showed that, the three isolates belong to phylum actinobacteria into the genus Streptomycetes. This study showed that media compositions, cultural conditions and solvents for extraction play an important role in bioactive compound production in these actinomycetes isolates.
It was found that the best initial $\mathrm{pH}$ value was $\mathrm{pH} 6.5$ at which the highest diameter of inhibition zone was recorded against the three tested bacterial pathogens (Figure 5). Throughout the growth period, $\mathrm{pH}$ value of the medium was changed while the best growth and antibiotic production are noticed at initial $\mathrm{pH} 7.0$ which became $\mathrm{pH} 5.9$ or $\mathrm{pH} 9.75$ depending to the strain (Wang et al., 2011). Isaacson \& Webster (2002) noticed that Xenorhabdus sp. RIO showed the best growth in culture broth at $\mathrm{pH} 7.07$ which decreased to $\mathrm{pH} 6.89$ during the first few hours of growth and the best $\mathrm{pH}$ value for growth varied from 6.5 to 8.5. Similarly, Yang et al. (2001) establish that initial $\mathrm{pH}$ value played an important role in the antibiotic production by Xenorhabdus nematophila. Moreover, incubation of the flasks at $30^{\circ} \mathrm{C}$ showed the best growth inhibition of the three tested bacterial pathogens

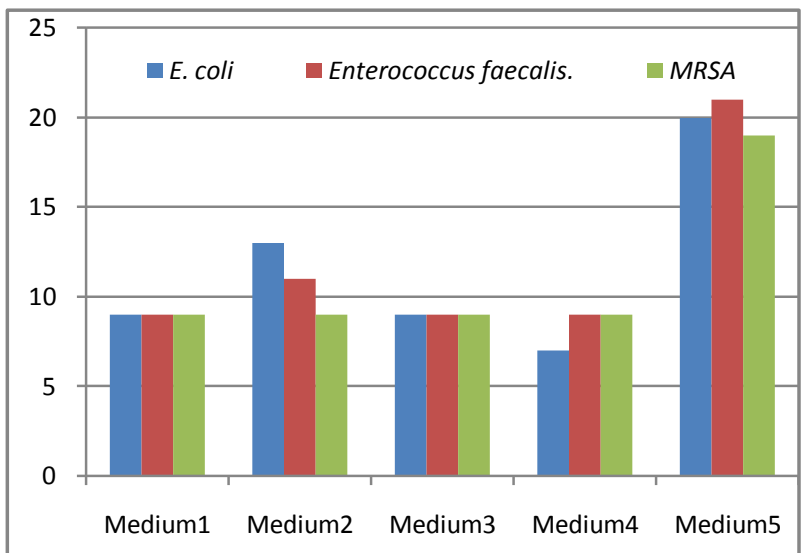

M1: Yeast extract starch peptone, M2: GBA-3, M3: Emerson medium, M4: Omura Medium, M5: Starch nitrate

Figure 4 Effect of different culture media after 4 days of incubation on production of antimicrobial agent by Streptomyces SD5 against three tested bacterial pathogens

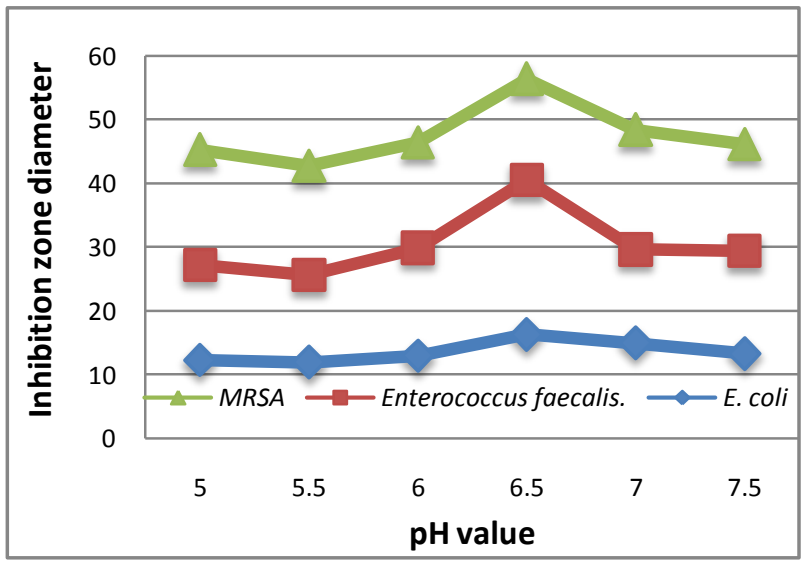

Figure 5 Effect of different $\mathrm{pH}$ value on the production of antimicrobial activity by the selected bacterium Streptomyces SD5 against three tested bacterial pathogens 


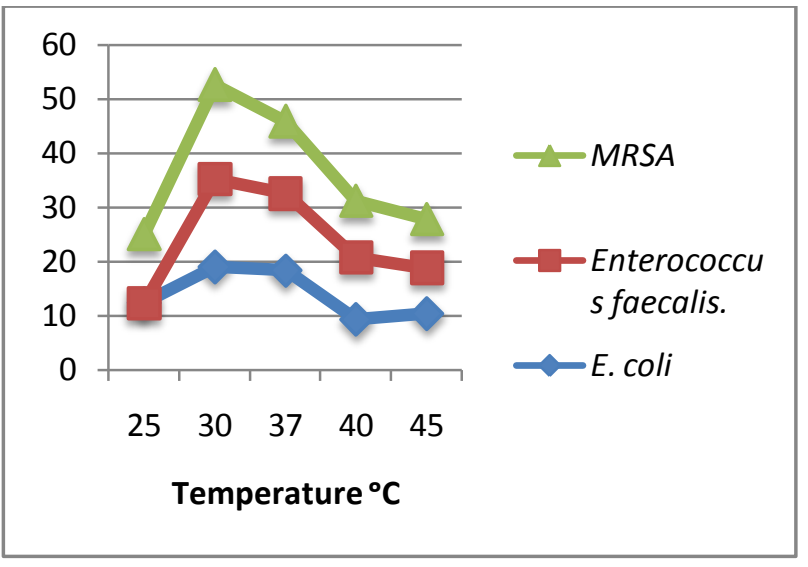

Figure 6 Effect of different incubation temperatures on production of antimicrobial activity by Streptomyces SD5 against three tested bacterial pathogens

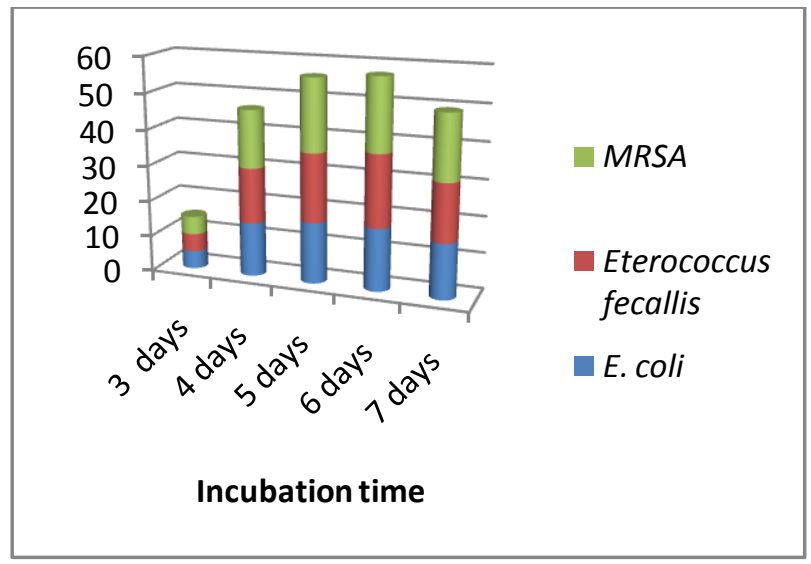

Figure 7 Effect of incubation period on antimicrobial agent production by Streptomyces SD5, used against three tested bacterial pathogens.

Table 4 Antibacterial activities (diameter of inhibition zone, mm) and Toxicity (LD50, $\mu \mathrm{g} / \mathrm{ml}$ ) of the different organic extracts obtained from the selected isolate Streptomyces SD5

\begin{tabular}{|c|c|c|c|c|}
\hline Tested extract & MRSA & Enterococcus faecalis & Escherichia coli & Toxicity (LD50, $\mu \mathrm{g} / \mathrm{ml})$ \\
\hline $\begin{array}{l}\text { Ethyl acetate } \\
\text { extract }\end{array}$ & $33.00 *$ & $25.33^{*}$ & $19.33^{*}$ & $>400$ \\
\hline $\begin{array}{l}\text { n- Butanol } \\
\text { extract }\end{array}$ & $10.67 *$ & $13.67^{*}$ & $19.33^{*}$ & $>400$ \\
\hline Petroleum ether extract & -ve & -ve & $20.00 *$ & $>400$ \\
\hline Control antibiotic (Ampicillin) & -ve & 43 & 33 & ND \\
\hline CuSO4 (1\%) & ND & ND & ND & 400 \\
\hline
\end{tabular}

while at higher or lower temperature, the activity decreased (Figure 6). Similarly, the effect of incubation period on antibacterial activity of the culture filtrate of the selected isolate SD5 was shown in Figure 7. After 5-6 days maximum inhibition was recorded against the three tested bacterial pathogens. The bioactive metabolite production started only after $48 \mathrm{hrs}$ of growth and reached a maximum inhibition zone $(19-20 \mathrm{~mm})$ against $E$. coli, E. faecalis and MRSA after 5-6 days. Effect of incubation period on antibiotic production was statistically significant where increasing time enhancing the antibacterial activity up to 6 days, then there was significant decreased in the antibacterial activity and biomass. Aliero et al. (2018) reported that incubation of the culture in shaking incubator at temperature range of $30-35^{\circ} \mathrm{C}, \mathrm{pH}$ (7.0-7.5) and incubation period (168 hr) were the best conditions for bioactive compound production. For extraction of the active material, laboratory scale production $(1500 \mathrm{ml})$ was prepared using starch nitrate broth which enhanced antimicrobial production by the isolate SD5 against MRSA, E. faecalis and $E$. coli. In 30 Erlenmeyer flasks $(250 \mathrm{ml})$, each contained $100 \mathrm{ml}$ of the growth medium with optimum $\mathrm{pH} 6.5$; these flasks were inoculated with the tested bacterium SD5 and incubated at the optimum temperature, determined from the previous experiment $\left(30^{\circ} \mathrm{C}\right)$ for 4 days. The culture filtrate was collected and extracted with the same volume of the different organic solvents (ethyl acetate, n-butanol or Petroleum ether). Extraction with ethyl acetate was the best where it gave the highest inhibition compared to n-butanol or petroleum ether (Table 4). From the tested strains, MRSA, E. faecalis and E. coli have been inhibited more than other tested isolates. Dhanaskaran et al. (2005) isolated Actinobacteria from soils of different regions of India with antimicrobial activities which were extracted with ethyl acetate, aniline, chloroform and pyridine but ethyl acetate extract was the best for bacterial pathogen inhibitions which was in accordance with the results of the current study. No toxicity was recorded up to $400 \mu \mathrm{g} / \mathrm{ml}$ for the different extracts obtained (Table 4) compared to the control, $\mathrm{CuSO}_{4}$ solution, which showed acute toxicity at $400 \mu \mathrm{g} / \mathrm{ml}$. Previous experimental analysis by Gamakaranage et al. (2011) reported the toxicity of $\mathrm{CuSO}_{4}$ at all 
Table 5 Minimal inhibitory concentration of the extracted material from Streptomyces SD5 using ethyl acetate and compared to control.

\begin{tabular}{|cccc|}
\hline Solvent & MRSA & $\begin{array}{c}\text { Enterococcus } \\
\text { faecalis }\end{array}$ & $\begin{array}{c}\text { Escherichia } \\
\text { coli }\end{array}$ \\
\hline SD5 & $75^{*}$ & $75^{*}$ & $100^{*}$ \\
\hline $\begin{array}{c}\text { Control antibiotic } \\
\text { (Ampicillin) }\end{array}$ & $-\mathrm{ve}$ & 5 & 5 \\
\hline
\end{tabular}

-ve: negative results *: Significant results, MRSA: Methicillinresistant Staphylococcus aureus

tested concentrations against animal cells and added that copper sulphate cause intravascular haemolysis, acute kidney injury and rhabdomyolysis. The lethal dose can be as small as $0.1 \mathrm{~g} / \mathrm{kg}$. A . salina was used as the test animal. Lucas et al. (2019) used $A$. salina and the same method to determine the toxic effect of some plant extracts and their results proved that this technique is the best for toxicity experiments. The detected MIC was ranged from $75-100 \mu \mathrm{g} / \mathrm{ml}$ while it was $5 \mu \mathrm{g} / \mathrm{ml}$ for the standard antibiotic (Table 5). Furthermore, species of genus Streptomyces produced $80 \%$ of the total used antibiotics and plant pathogen inhibitors (Oskay et al. 2004; Jeffrey, 2008; Arifuzzaman et al., 2010). Actinomycetes present in any specific soil and their numbers were influenced by the soil type, geographical location, cultivation and organic matter (Arifuzzaman et al., 2010). Various studies have been done by scientists to isolate actinoacteria for antibiotic discoveries. Although actinomycetes occurred widely in nature, only a small numbers of actinomycetes have been screened for antibiotics productions (Kumar et al., 2010). Many antibiotic producing actinomycete strains were generally isolated from soil. In conclusions, resistance to antibiotic is increased and actinomycetes is excellent source of new and active antibiotics

\section{Conflict of interest}

No potential conflict of interest was reported by the authors.

\section{References}

Agwa A, Aly MM, Bonaly R (2000) Isolation and characterization of two Streptomyces species produced non polyenic antifungal agents. Journal Union Arab of Biology 7 B: 62- 84

Aliero AA, Adam AS, Ntulume I, Bagudo AI, Kudu A, Ondieki MC, Jega SA, Odda J, Okech MA (2018) Molecular characterization and optimization of bioactive compounds production of three actinomycetes spp isolated from waste dump soil from Western Uganda. Current Trends in Biotechnology and Pharmacy, 12: 230-244.

Aly MM, El-Sabbagh SM (2004) Nile-water sediments as a source of actinomycetes exhibiting biomedical activity.
Proceedings 3th International Conference Biological Science Tanta University, Egypt, 27-28 April, 2004.

Aly MM, Gumgumjee NM (2011) Antimicrobial efficacy of Rheum palmatum, Curcuma longa and Alpinia officinarum extracts against some pathogenic microorganisms. African Journal of Biotechnology 10: 12058-12063.

Aly MM, Sanaa Totk, Saleh M. Al-Garni, Reda Allam (2013) Production and characterization of uricase from Streptomyces exfoliates UR10 isolated from farm wastes. Turkish Journal Biology 37: 520-529.

Aly MM, Tork S, Al Garni S, Nawar L (2012) Production of lipase from genetically improved Streptomyces exfoliates LP10 isolated from oil contaminated soil. African Journal of Microbiology Research 6: 1125-1137.

Aly MM, Tork S, Al-Garni S M, Kabli S A (2015) Production and characterization of phytase enzyme from Streptomyces luteogrises R10isolated from decaying wood sample. International Journal Agriculture and Biology 17:-515-522.

Amer S, Aly MM, Sabbagh S (2006). Biocontrol of dermatophytes using some plant extracts and actinomycetes filtrates. Egyptian Journal Biotechnology 14: 291--315.

American Thoracic Society and Infectious Diseases Society of America (2005) Guidelines for the management of adults with hospital-acquired, ventilator-associated, and healthcare-associated pneumonia. American Journal of Respiratory and Critical Care Medicine $172: 1169-227$.

Arifuzzaman M, Khatun MR, Rahman H (2010) Isolation and screening of actinomycetes from sundarbans soil for antibacterial activity. African Journal of Biotechnology 9: 4615-4619.

Berdy J (2005) Bioactive microbial metabolites. Journal of Antibiotic (Tokyo) 58: 1-26.

Bonnavero V, Chevaleier J, Cremieux A (1998) A Rapid Method Outomatized Method for Assyment of the Fungal Activity of Natural and Synthetic Agents. In 6th Congress mediterania of Chemotherapy, Taormina, Italy, Pp. 2227.

Dhanasekaran D, Raja-Kumar G, Sivamani P, Sivamani N, Paneerselvam A, Thajuddin N (2005) Screening of salt pans actinomycetes for antibacterial agents. International Journal Microbiology 1:6-12.

Ebadi S, Sohrabi H, Peymani A, Sarookhani M R (2018) Identification of antibiotic-producing streptomyces species in Iran's soil by phenotypic and genotypic methods. Biotechnology and Health Sciences 5:e59854. 
Frieden T (2013) Antibiotics resistance threats in the United State. Centers for Disease Control and Prevention, U. S Department of health and human services.

Gamakaranage SSK, Rodrigo C, Weerasinghe S, Gnanathasan A, Puvanaraj V, Fernando H (2011) Complications and management of acute copper sulphate poisoning; a case discussion. Journal of Occupational Medicine and Toxicology 6:34.

Ghanem NF, Aly MM (2003) Antitumor activity of Streptomyces (AFS99) against the induced-liver tumorigeneses in mice. Journal Medical Research Institute 24: 88-106.

Helmi NR, Zaman RM, Aly MM (2013) Prevalence of grampositive bacteria in Jeddah, Kingdom of Saudi Arabia: Study of antimicrobial resistance patterns and molecular typing. International Journal Pharm Bio Science 4: 1231 - 1245.

Hindler JA, Inderlied CB (1985) Effect of the source of MuellerHinton agar and resistance frequency on the detection of methicillin-resistant Staphylococcus aureus. Journal Clinical Microbiology 21: 205-210.

Hyun DY, Mason EO, Forbes A, Kaplan SL (2009) Trimethoprim-sulfamethoxazole or clindamycin for treatment of community acquired methicillin-resistant Staphylococcus aureus skin and soft tissue infections. Pediatric Infectious Disease Journal 28:57-9. 20.

Isaacson PJ, Webster JM (2002) Antimicrobial activity of Xenorhabdus sp. RIO (Enterobacteriaceae), symbiont of the entomopathogenic nematode, Steinernema riobrave (Rhabditida: Steinernematidae). Journal of Invertebrate Pathology 79:146-153.

Janardhan A, Kumar A, Viswanath B, Saigopal DVR, Narasimha G (2014) Production of bioactive compounds by actinomycetes and their antioxidant properties. Biotechnology Research International, Article ID 217030, 8 pages.

Jeffrey LS (2008) Isolation, characterization and identification of actinomycetes from agriculture soils at Semongok, Sarawak. African Journal Biotechnology 7: 3697-3702.

Jiao W, Zhang F, Zhao X, Hu J, Suh JW (2013) A novel alkaloid from marine-derived actinomycete Streptomyces xinghaiensis with broad-spectrum antibacterial and cytotoxic activities. PLoS ONE 8(10): e75994. doi:10.1371/journal.pone.0075994.

Kaur DC, Chate SS (2015) Study of Antibiotic Resistance Pattern in Methicillin Resistant Staphylococcus Aureus with Special Reference to Newer Antibiotic. Journal of global infectious diseases 7:78-84.
Kaur DC, Narayan PA (2014) Mupirocin resistance in nasal carriage of Staphylococcus aureus among healthcare workers of a tertiary care rural hospital. Indian Journal of Critical Care Medicine 18:716-21.

Kekuda TRP, Shobha KS, Onkarappa R (2010) Fascinating diversity and potent biological activities of Actinomycetes metabolites. Journal of Pharmacy Research 3: 250-256.

Koehn FE, Carter GT (2005) The evolving role of natural products in drug discovery. Nature Reviews Drug Discovery 4: 206-220.

Kumar N, Singh RK, Mishra SK (2010) Isolation and screening of soil actinomycetes as sources of antibiotics active against bacteria. International Journal of Microbiology Research 2: 12 -16.

Laverde Gomez JA, Hendrickx AP, Willems RJ, Top J, Sava I, Huebner J, Witte W, Werner G (2011) Intra- and interspecies genomic transfer of the Enterococcus faecalis pathogenicity island. PLoS One 6 : e16720.

Lee DS, Lee SJ, Choe HS (2018) Community-acquired urinary tract infection by Escherichia coli in the era of antibiotic. BioMed Research International 7656752. DOI: https://doi.org/10.1155/2018/7656752.

Lucas CP, Oliveira R, Neto J, Schmidt R, Salvi C, da Silva F (2019) Evaluation of cytotoxic and mutagenic activities of Tabebuia aurea (Silva Manso). IOSR Journal Of Pharmacy 9: 62-69.

Luna CM, Noriega ER, Bavestrello L, Gotuzzo E ( 2010) Treatment of methicillin-resistant Staphylococcus aureus in Latin America. Brazilian Journal of Infectious Diseases 14 (Suppl. 2): S119-S127.

Madappa T (2014) Escherichia coli infections medication. Available on http://emedicine.medscape. com/article/ 217485medication access on $21^{\text {st }}$ January, 2019.

Meyer BN, Ferrigni NR, Putnan JE, Jacobs LB (1982) Brine shrimp: a convenient general bioassay for active plant constituents. Planta Medica 45: 31-34.

Moran GJ, Krishnadasan A, Gorwitz RJ, Fosheim GE, Albrecht V, Limbago B, Talan DA (2006) Methicillin-resistant S. aureus infections among patients in the emergency department. New England Journal of Medicine 355:666-74.

Naine J, Srinivasan MV, Devi SC (2011) Novel anticancer compounds from marine Actinomycetes : a review. Journal of Pharmacy Research 4: 1285-1287 
NCCLS (2002) Reference method for broth dilution antifungal susceptibility testing of yeasts; Approved Standard-Second Edition. NCCLS document M27-A2 (ISBN 1-56238-469-4), NCCLS, 940 West Valley Road, Suite 1400, Wayne, Pennsylvania 19087-1898 USA.

Omura S, Takahashi Y, Iwai Y, Tanaka H (1982) Kitasatosporia, a new genus of the order Actinomycetales. Journal of Antibiotic 35:1013-1019.

Oskay M, Usame A, Azeri C (2004) Antibacterial activity of some actinomycetes isolated from farming soils of Turkey. African Journal Biotechnology 3: 441- 446.

Otsuki T, Kumar S, Kingma DW, Yano I, Stetler-Stevenson M, Jaffe ES, Raffeld M (1996) Detection of HHV-8/KSHV DNA sequences in AIDS-associated extranodal lymphoid malignancies. Leukemia 10: 1358-1362

Pandey B, Ghimire P, Agrawal VP (2004) Studies on the antimicrobial activity of actinomycetes isolated from Khumbu region of Nepal. Ph. D. Thesis submitted to the Tribhuvan University, Kathmandu, Nepal.

Peacock SJ, Paterson GK (2015) Mechanisms of Methicillin Resistance in Staphylococcus aureus. Annual Review Biochemistry 84:577-601.

Rabah S, Azab E, Aly MM (2007) Studies on bacterioplankton and inhibitory strains of actinomycetes in lake Bardawil, Egypt. World Journal Microbiology Biotechnology 23:111-116.

Rabah S, Azab E, Aly MM (2006) Efficiency of waste stabilization pond in removing some pathogenic bacteria and the possible role of aquatic actinomycetes. New Egyptian Journal Microbiology 15: 186-203.

Sader HS, Moet GJ, Jones RN (2009) Antimicrobial resistance among Gram-positive bacteria isolated in Latin American hospitals. Journal Chemotherapy 21: 611-20.

Salami F (2004) Isolation and determination of Streptomyces that produce antibiotic from soil. Pajohesh-ve-Sazandegi 17:41-47.

Sangian H, Faramarzi H, Yazdinezhad A, Mousavi SJ, Zamani Z, Noubarani M (2013) Antiplasmodial activity of ethanolic extracts of some selected medicinal plants from the northwest of Iran. Parasitological Research 112:3697-3701.

Shirling EB, Gottlieb D (1966) Cooperative description of type cultures of Streptomyces. II. Species descriptions from first study. International Journal Systematic Bacteriology18:169-89.

Shittu AO, Udo EE, Lin J (2009). Phenotypic and molecular characterization of Staphylococcus aureus isolates expressing low- and high-level mupirocin resistance in Nigeria and South Africa. BMC Infectious Diseases 9:10-19.

Tork SE, Aly MM, Elsemin O (2018) A new l-glutaminase from Streptomyces pratensis NRC 10: Gene identification, enzyme purification, and characterization. International Journal of Biological Macromolecules 113:550-557.

Torsvik V, Ovreas L (2002) Microbial diversity and function in soil: from genes to ecosystems. Current Opinion in Microbiology 5: $240-245$

Wang Y, Fang X, Cheng Y, Zhang X (2011) Manipulation of pH shift to enhance the growth and antibiotic activity of Xenorhabdus nematophila, Journal of Biomedicine and Biotechnology Article ID 672369, 9 pages.

Weisburg WG, Barns SM, Pelletier DA, Lane DJ (1991) 16S ribosomal DNA amplification for phylogenetic study. Journal of Bacteriology $173: 697-703$.

Westley JW, Evans RH, Sello LH, Troupe N, Liu CM, Blount JF (1979) Isolation and characterization of antibiotic X-14547A, a novel monocarboxylic acid ionophore produced by Streptomyces antibiotics NRRL 8167. Journal Antibiotic 32: 100-107.

Woodward S (2015) E. coli: A brief overview. British journal of nursing 24:158-160.

Yang X, Yang W, Jian H (2001) Effect of fermentation conditions on antibiotic production of Xenorhabdus nematophilus. Chinese Journal of Microbiology 28: 12-16.

Zaman R M, Aly M M and Helmi N R (2015) Antimicrobial susceptibility pattern of Gram-negative bacilli isolated from a Teaching Hospital in Jeddah, Saudi Arabia. African Journal of Biotechnology 9: 2145-2158. 